slates of North Wales, where soon he becams absorbed in a new interest- "the petrology of the igneous rocks associated with the Cambrian (Sedguick) system of Carnarvonshire"-and endeavoured to trace the relationship of the igneous phenomena of the district and concurrently operating crustal stresses, a theme which he was greatly to amplify in his later writings. Tho results of this work wero incorporated in the Sedgwick Prize Essay for 1888. During 1889-93 ho was engaged in the Lake District where, in collaboration with J. E. Marr, he traced a varied group of lavas, ashes and sediments into the aureole of the Shap Fell granite. These papers form pioneer contributions on the nature and origin of metamorphic rocks and rank with Rosenbusch's classical studies on the Steigerschiefer of the Vosges.

With a reputation now thoroughly established, Harker, at the instance of Sir Archibald Geikie, was seconded in 1895 to the Geological Survey of Scotland for summer field work in Skye. The mapping of the mountainous groups of the Cuillins and the Red Hills of central Skye which followed, was completed in 1901 , and will ever remain as a monument to his shill and ardour as a field geologist, and disposed finally of the embittered controversies of Judd and Geilive on the igneous succession of that island.

The outcome of his researches in Sliye, and later in Rum, appeared in two Survey memoirs - "The Tertiary Igneous Rocks of Skye" (1901) and "The Geology of the Small Isles of Inverness-shire" (1908)and at once attracted wide attention. Considering the time of their execution, and as the work of one individual, these researches will always rank as one of the greatest achievements in igneous geology.

The way was now prepared for Harker to present to a wider audience his long-considered viows on the broad aspects of magmatic descent and the controlling influence of tectonic environment. These problems, among others, he unfolded in his "Natural History of Igneous Rocks" (1909). Written in an extremely lucid style and with a rare power of philosophical generalization, this volume has come to exert a deep influence on petrologic thought. If some of his conclusions have needed amendment, in its broad lines, his achievement has been none the less fundamental.

The same philosophic outlook characterized Harker's presidential addresses to the Geological Society. In the last of these he returned once more to the subject of metamorphism, a field which became his dominant interest in later years. His final work appeared in 1932 under the title "Metamorphism", a treatise which has been appraised in the words of an acknowledged authority as filling "an important place in the literature of petrology, and in lucidity, balance and breadth of view can serve as a model to all future writers on the anatomy and history of rocks".

Harker was elected a fellow of the Royal Society in 1902 and awarded a Royal Medal in 1935. From the Geological Society of London he received in succession the Murchison and Wollaston Medals. Honorary doctorates were conferred upon him by the University of Edinburgh and McGill University, while he was honorary or corresponding member of many scientific societies, British and foreign. These honours he accepted with such extraordinary modesty that many of them remained hidden and unsuspected by even those most intimate with him.

Harker's elementary lectures mado little appeal to the average Tripos man, but ho excelled in contact with senior students, and his advanced courses became the source of inspiration to many generations of students.

After his retirement in 1931 , and to within a fow weeks of his death, he continued to devote much time to the care of the petrological collections of the University. In the Harker Collection of rock slices numbering now some 40,000 slides neatly labelled in his own handwriting and representative of research material drawn from all quarters of the globe, he has endowed his department with a unique monument.

At St. John's College, where he had been for some years the senior fellow in residence, he was rather a lone figure, though on his retirement he seemed to cast off some of his natural reserve. By his old pupils he was held in affectionate regard, and the expression of this esteem was signally evoked at the dinner held in his honour at Cambridge on the occasion of his eightieth birthday. Thoso who were privileged to have his confidence and companionship will retain a lasting memory of the generosity and humility of a truly great man.

C. E. T.

\section{Mr. W. Scoresby Routledge}

WE regret to record the death of Mr. WV. Scoresby Routledge, traveller and anthropologist, which took place suddenly at Paddington on July 31 in his eightieth year.

William Scoresby Routledge was born at Melbourne in 1859 and was educated privately and at Christ Church, Oxford, graduating in 1882. He then entered University College Hospital, London, where ho was Erichsen prizeman in operative surgery. He was, howover, at heart an explorer, and for many years lived among primitive peoples. With the Micmacs of central Newfoundland, primitive tribes at that time still living mainly by hunting and fishing, he became proficient in woodcraft and learned to endure conditions which to tho ordinary civilized individual would appear to border on privation. This early training served him to good purpose in his later travels, more especially during his stay among the Akikuyu of East Africa Colony, now Kenya, with whom he lived at a time when there was little exaggeration in terming them a 'prehistoric' peoplethe title he gave them in the valuable study of their manners and customs in "With a Prehistoric People" (1910), of which he was the joint author with his wife, Katherine, the daughter of the late Gurney Pease of Darlington, whom he married in 1906.

Mrs. Routledge, who had read history at Oxford, guided by the influence of Dr. R. R. Marett, was no less a keen anthropologist than her husband, and even while their joint book on the Kikuyu was in the making they were already planning their next and most important expedition. This was a journey 
to Easter Island to investigate and explore systematically the antiquities of that island, and more especially the origin and meaning of the sculptured statues and the script for which the island is famous, and of which the meaning had long been sought by travellers and anthropologists. The expedition, which sailed in a small schooner-rigged yacht with auxiliary power, named the Mana, which Routledge had built for the purpose, was in Easter Island when the War broke out in 1914. It returned to England in 1916, after visiting a number of islands in the Pacific, including Pitcairn, from which they brought back two descendants of Young, the mutineer officer of the Bounty, whom they presented to His Majesty King George V in an interview in July 1916. Further research on the history of Easter Island was carried out in 1920 and 1922, when tho Routledges visited and surveyed tho Austral and Gambier groups and collected much valuable anthropological material bearing on distribution. The results of the earlier expedition wero published in a volume "The Mystery of Easter Island" which appeared in 1919.
WE regret to announce the following deaths :

Sir Edward Brown, former secretary of the National Poultry Council and first president of the World's Poultry Scienco Association, on August 7, aged eighty-soven years.

Miss A. R. Clark, librarian at the Laboratory of the Marine Biological Association of the United Kingdom at Plymouth.

Dr. Edmund Heller, director of the Fleishhacker Zoological Park, formerly director of the Milwaukee Zoological Gardens, on July 18, aged sixty-four years.

Prof. L. Lévy-Bruhl, professor of philosophy in the Sorbonne during 1899-1927, president of the Institut française d'Anthropologie during 1927-30, aged eighty-two years.

Dr. Heinrich Poll, formerly director of the Anatomical Institute, Hamburg, on Juno 12.

Prof. WV. A. Tarr, professor of mineralogy and geology in the University of Missouri, on July 28, aged fifty-eight years.

\section{NEWS AND VIEWS}

\section{Memorial to Sir William Perkin}

Ir was a pleasing thought of the people of Sudbury, now part of the new borough of Wembley, and of the friends of the late Sir William H. Perkin, to commemorate his long residence there by the erection of a memorial in the form of a tiny garden of rest and a large oval oak seat. The memorial was unveiled by the eldest Niss Perkin on August 12 in the presence of the civic authorities, the church, some friends and a large number of the public. An appropriate oration on Perkin's life and work was given by Dr. C. E. Goddard. The growth of London has swept away the peaceful home and garden and fields where Perkin retired to in 1874 to devote his life to research; he became also a good citizen and much beloved in the village. The memorial stands on a corner of his land, the noisy traffic thunders past it on two sides and there is a round-about in front. But this tiny spot is a haven of refuge and peace, and those who use it for a few moments in years to come can read the tablet and muse perhaps on what lind of a man was this Perkin, founder of the dye industry. 'Scientist and citizen' might appropriately have been added, for it was as the latter, a man conspicuous for his probity and good works, that Sudbury knew him.

\section{Ship-Burial and Treasure Trove in Suffolk}

TnE verdict of the jury at the coroner's inquest, which took place on Aug. 14, on the Anglo-Saxon ship-burial, or rather on the grave furniture in precious metals found therein, at Sutton Hoo in Suffolk (see NAtUre of August 5, p. 239), was such as, perhaps, might well have been expected. It would bo more than diffeult to argue convincingly that a royal burial, in the circumstances indicated here by the character of the relies, could have taken place with that secrecy and intention to resume possession, which have been laid down from time to time in legal pronouncement as the essential principle of 'treasure trove'. Unless the matter is carried further in the High Court, as Mr. I. H. Vulliamy, the coroner, indicated as a possibility, the Sutton Hoo treasure now becomes legally the property of Mrs. E. M. Pretty, the owner of the land upon which the burial was found by Mr. Guy Maynard of the Ipswich Mruseum. It may be hoped, however, that arrangements will be made in due course to ensure its display to the public and availability for study, as its historic interest demands. It would now appear, since there has been an opportunity for the articles to be examined and eleaned in the British Museum, that the find is far more valuable than was at first reported. This is shown in the evidence of Mr. C. W. Phillips of Selwyn College, Cambridge, who had been in charge of the opening of the tumulus since July, and also in a supplementary note contributed by The Times museum correspondent in the issue of August 15 which mentions more especially the silver. The objects in this metal include six shapely shallow bowls in almost perfect preservation, about 8 or 9 inches across, and all provincial Byzantine or late Roman. They are decorated with a broad cross, usually of a quatrefoil pattern. A silver dish decorated with a classical woman's head is provincial Byzantine work of the sixth century. A large platter, 28 inches across, was made at Constantinople, and bears marks of the reign of Anastasius I. The gold work, however, 